\title{
Out-of-Class Instruction in Higher Education
}

\section{- Impact of Approaches to Teaching and Discipline}

\author{
Lena Päuler-Kuppinger ${ }^{1} \&$ Regina Jucks ${ }^{1}$ \\ ${ }^{1}$ University of Muenster, Germany \\ Corresponding Author: Prof. Dr. Regina Jucks, University of Münster, Department of Psychology and Sport Studies, \\ Fliednerstraße 21, 48149 Münster, Germany.
}

Received: February 22, 2018

Accepted: April 5, 2018

Online Published: April 10, 2018

doi:10.5430/ijhe.v7n2p199

URL: https://doi.org/10.5430/ijhe.v7n2p199

\begin{abstract}
Many debates in higher education center around the role of approaches to teaching (measured with ATI-R) and impact of academic disciplines (soft vs. hard) on teaching practice, e.g. advice giving. An online study with $\mathrm{N}=70$ academic teachers was conducted and the advice given was content analyzed. Regression analyses showed that academics with a higher student focus (ATI-R) advised more deep learning strategies. Academics from the soft disciplines wrote longer answers, advised more resource management strategies, and provided more reasons for student self-learning that contained fewer external motivators. Hence, the study supports the role of approaches to teaching and academic disciplines on teaching practice.
\end{abstract}

Keywords: approaches to teaching, ATI-R, disciplines, out-of-class communication, advising

\section{Introduction}

Academic teachers' teaching practice and its professionalization is an important field in higher education research because it affects the ways in which students' study (e.g. Biggs, 1999, cited in Entwistle \& McCune, 2004). Academic teachers, in the following referred to as academics, are defined as postgraduate faculty and staff who teach in higher education institutions, especially universities. Thinking and decision-making by academics involve highly contextualized and complex processes (Eley, 2006; Martin, Prosser, Trigwell, Ramsden, \& Benjamin, 2000). The complexity of academics' teaching practice demands research designs that reduce complexity on data acquisition levels by examining a relevant and yet restricted part of teaching behavior (Amudsen \& Wilson, 2012; Eley, 2006).

This study aims at examining academic teaching behavior in conjunction with academic disciplines-and identity (Neumann, 2009). Secondly, it focuses on academics' intentions and strategies used to design their teaching (Trigwell \& Prosser, 1996). Furthermore, professionalization often addresses academics' approaches to teaching based on the assumption that they translate directly into academics' teaching behaviors, even though concrete observations of this association are lacking (Kane, Sandretto, \& Heath, 2002). This study utilizes the electronic Email communication between university academics and their students (Jucks \& Brummernhenrich, 2016; Waldeck, Kearney, \& Plax, 2001). This paper reports how academic disciplines and approaches to teaching, relate to advice giving to students.

\section{Literature Review}

Approaches to teaching

Approaches to teaching' describe the intentions and strategies teachers use to design their teaching (Trigwell \& Prosser, 1996) and may constitute behavior-oriented descriptions of conceptions of teaching, reflecting the belief system that underlie preferred approaches to teaching (Lübeck, 2009). This research examines how approaches to teaching translate into teaching practices under the broader concept of 'conceptions' of teaching.

Student-focused and Teacher-focused approaches. The literature concerning approaches to teaching distinguish between teacher/content and student/learning approaches to teaching (Kember, 1997). Academics who approach their teaching in a teacher/content-oriented way concentrate on what they 'do' in teaching to transmit particular information (Kember \& Kwan, 2000; Trigwell, 2012) based upon their own knowledge (Trigwell, Prosser, \& Ginns, 2005). They use examples from their own experiences without utilizing the students' experiences (Kember \& Kwan, 2000; Trigwell et al., 2005). Students are viewed as passive recipients (Kember, 1997) and treated equally under a 
group focus (Kember \& Kwan, 2000). Academics repeat traditional and familiar ways of teaching (Postareff \& Lindblom-Ylänne, 2008) and transmit certain skills, such as structuring, presentation, forward planning and good management (Kember, 1997; Trigwell et al., 2005).

Academics who teach with a student/learning orientation concentrate on how students' understanding, learning and knowledge constructions can be facilitated, and how students can be supported in their conceptual change (Kember, 1997; Trigwell, 2012). They encourage students to discover and construct knowledge, by utilizing the students' experiences (Kember \& Kwan, 2000) and are motivated to challenge current ideas through questions or discussion (Trigwell et al., 2005). They regard motivating students as an intrinsic part of their teaching role (Kember \& Kwan, 2000) and show understanding recognizing student individuality, respecting they have their own interpretive contextual frameworks (Kember, 1997; Kember \& Kwan, 2000). Important teaching goals for this approach are located within the students themselves, rather than being teacher-driven,_and involves their understanding and ability to apply knowledge (Kember, 1997).

Previous research indicates that students in groups learn better with student/learning approaches to teaching, than with teacher/knowledge approaches when considered through examination marks and failure rates-(Baeten, Kyndt, Struyven, \& Dochy, 2010, Gibbs \& Coffey, 2004; Trigwell, Prosser, \& Waterhouse, 1999).

To sum up, there are benefits to applying student/learning and teacher/knowledge approaches. Academics are assumed to possess a repertoire of approaches to teaching that can be adjusted, at least partially, when the demands of the teaching and learning environment require the academic focus on a particular facet of their approach. This integral view is supported by studies that identified profiles or 'dissonant' characteristics within academics' approaches to teaching; reporting how features from both approaches at the same time impact learning (Kember, 1997, Postareff \& Lindblom-Ylänne, 2008; Stes \& Van Petegem, 2014). Research by Postareff and Lindblom-Ylänne (2008) reported that the student/learning approach to teaching was more a 'complete' and sophisticated approach compared to aspects of the teacher/content approach to teaching. Academics with a student-focused conception understand that transmission is necessary but not sufficient for deep learning (Trigwell et al., 2005). The student/learning and teacher/knowledge approaches are mirrored in the Approaches to Teaching Inventory-Revised (ATI-R, Trigwell et al., 2005), an instrument used to assess different teaching approaches. The ATI-R is adopted in many professional initiatives that reflect teaching approaches to promote student-oriented approaches (Amundsen \& Wilson, 2012; Trigwell, et al., 2005).

Impact of approaches to teaching on teaching practice. Many studies that claim academics' approaches to teaching impact directly their teaching behavior lack empirical evidence (Kane et al., 2002). This might be because it is difficult to grasp the direct significant impacts of approaches to teaching on teaching practice (see Devlin, 2006). One reason for this is that there is often a discrepancy between someone's attitude and their behavior (e.g. Eley, 2006; Kane et al., 2002). What makes it so difficult to grasp an association between approaches and behavior is that a teacher's thinking and decision making are highly contextualized processes, in which factors such as student characteristics, the object of study, and environmental features all influence their actions (see Eley, 2006; Martin et al., 2000).

Though this makes it very difficult to study the impact of approaches to teaching on teaching behavior, there are strong arguments that support this functional role of approaches to teaching (e.g. Ho, Watkins, \& Kelly, 2001; Kember \& Kwan, 2000; Trigwell \& Prosser, 1996). To contribute to this discourse, an operationalization of teaching behavior is presented that reduces the complexity of teaching behavior and yet includes aspects that can be regarded relevant expressions of approaches to teaching and can be explored adopting disciplinary considerations.

\section{Academic disciplines}

In higher education, academic discipline is an important context criterion: Disciplines differ in epistemological characteristics, which impact their way of thinking, their methodologies to approaching a problem and their ways of explaining phenomena (Neumann, Parry, \& Becher, 2002).

Academic disciplines are grouped most often into the non-paradigmatic soft domain - containing social sciences and the arts - and the paradigmatic hard domain - containing the natural sciences and mathematics (Muis, Bendixen, \& Haerle, 2006; Neumann et al., 2002). Additional categories to typify disciplines have been stated by, for example, Kolb, Biglan, and Becher and Trowler (cited in Neumann, 2009), but the hard-soft dimension has proven to be the strongest in terms of explained variance (Neumann, 2009) and was therefore used in this study. The differences between soft and hard disciplines incorporate epistemological attributes that are explicitly showcased in the faculties' domain-specific epistemological beliefs: Taken to extremes, members of soft disciplines believe that knowledge is 
rather complex, interwoven, and subject to greater interpretation, whereas members of hard disciplines consider knowledge rather as discrete elements that are known with certainty (Hofer, 2000; Päuler \& Jucks, 2017). It has also been shown that academics' (and students') approaches to teaching differ depending on their academic discipline: characteristics of a student-focused approach, such as group work and critical thinking, are more prominent in the soft disciplines, whereas teacher-focused approaches, such as traditional lectures and opportunities to ask questions, are more salient in the hard disciplines (Päuler \& Jucks, 2017).

\section{Online out-of-class communication}

Academics' mode of communication is an important factor that contributes to effective teaching (Trigwell \& Shale, 2004; Young, 2006). In addition to in-class-communication, academics instruct students in important ways outside of the classroom, e.g. in after-class conversations, during planned meetings or by email communication (Jucks \& Brummernhenrich, 2016; Waldeck et al., 2001). Email has become „,a viable medium through which learning can be facilitated" (Waldeck et al., 2001, p. 55). Research on this relevant part of teaching behavior is scarce.

This study aims to systematically explore university academics' online communication when students ask about learning-related topics, such as Why it is important for students to invest in self-learning?, How do academics motivate students to invest effort in self-learning?, What strategies can students use for self-learning? and What strategies do academics advise?. These questions are of specific importance because the way academics communicate about learning-related topics mirrors their teaching practice and is associated with their teaching and learning knowledge, their conceptions about and approaches to teaching, as well as the knowledge of their discipline (Trigwell \& Shale, 2004). Thus, online out-of-class communication serves as a meaningful facet of teaching practice in order to explore associations between teaching practice and approaches to teaching and academic discipline.

\section{Research question and hypotheses}

The aim of this research is to examine how academics' methods of explaining reasons and giving advice are influenced by their approaches to teaching and academic disciplines. The research was structured around the following research questions:

\section{How are university academics' approaches to teaching related to their communication behavior} in out-of-class email communication?

2. What effects does a guided reflection on a particular approach to teaching have on the reflection content and academics' communication behavior?

3. How is the academic discipline associated with academics' explanations and advice-giving behavior?

\section{Method}

\section{Participants}

Academics were recruited from three large German universities via personalized email using addresses openly accessible on Faculties' internet websites. 70 academics participated and received a 20-euro voucher for their time. The participants were recruited evenly from one of two discipline-groups resulting in 35 academics each from a mathematics or natural science faculty (chemistry, mathematics, biology), and a social science or arts faculty (German studies, history, English studies). No differences between groups of discipline were found for age, teaching experience or vocational training. The academics' mean age was 39.05 years and $51 \%$ were female. Of the 70 participants, 46 were research and teaching associates (66\%) 18 were full professors (26\%), and 6 were lecturers with teaching but no research obligations (9\%). Their teaching experience did not differ between domains.

A comparison of gender proportions revealed that there were significantly fewer women from mathematics or natural science faculties (34\%; compared to 69\% women in social sciences and arts), and that academics from a mathematics or natural science faculty had significantly more research experience, than academics from a social sciences or arts faculty. Hence, gender and research experience were implemented into analyses as covariates.

\section{Design and procedure}

The research combined a correlational and quasi-experimental research design. The main research questions addressed the association between academics' approaches to teaching, disciplines and responses to a student request, thereby representing a correlational research design. The academics' systematic recruitment from the disciplines (hard or soft domain) constituted a quasi-experimental factor, and the salience of one approach to teaching (teacher-/content-focus or student-/learning-focus) was regarded as an experimental factor, resulting in a $2 \times 2$ 
quasi-experimental design added to the correlational study. Figure 1 shows the design factors and order within the procedure.

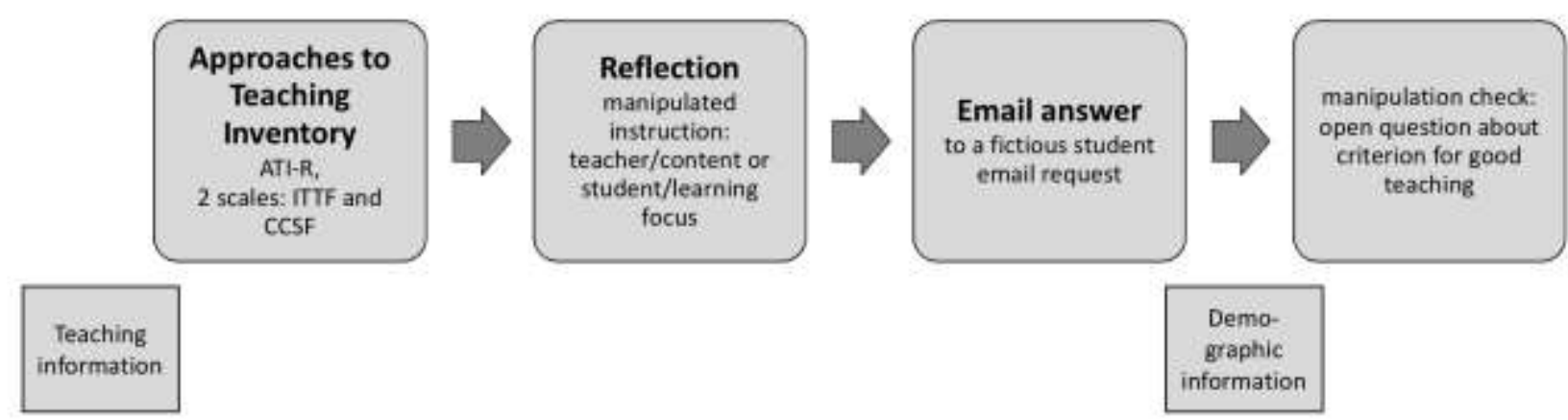

Figure 9. Illustration of study procedure.

The study was conducted online using Questback EFS Survey software. Academics were asked to participate in a survey on their beliefs about teaching and specific teaching requirements. In order to direct the academics' attention at a particular teaching context for the following tasks, they were asked to select one particular course from their teaching portfolio and to describe what kind of course they were giving for what group of students. This focusing on a particular teaching context is also required within the ATI-R instructions (Trigwell et al., 2005) that followed in a second step.

Following the ATI-R, academics were given one of two different sets of instructions encouraging them to reflect on their teaching practice. These two sets of instructions aimed to make one of the two approaches to teaching (teacher-focused or student-focused) salient.

Academics were then asked to answer the student's request, which was visually presented in a manner similar to what one would find using a common email program.

Finally, the academics answered some demographic questions and an open question on their most important criterion for good teaching. The open question served as a manipulation check to make sure the teaching approach emphasized in the reflection on their personal teaching practice was indeed made salient. Academics needed an average of 29.19 minutes $(S D=13.62)$ to complete the survey.

The following describes the measures and materials in order of appearance within the survey.

\section{Materials and measures}

Approaches to Teaching Inventory (ATI-R). Academics' approaches to teaching were assessed using the Approaches to Teaching Inventory (ATI-R) by Trigwell, Prosser, and Ginns (2005; German translation by Lübeck, 2009). The inventory contains 11 items that assess an information transmission/teacher focus (ITTF) approach e.g. 'It is important to present a lot of facts to students so that they know what they have to learn for this subject.', and 11 items tapping a conceptual change/student focus (CCSF) approach to teaching e.g. 'I see teaching as helping students develop new ways of thinking in this subject.'. Participants rated the items with reference to the particular course they had described in the beginning of the survey on a 5-point scale ranging from 1 (almost never) to 5 (almost always). Internal consistencies were satisfactory with $\alpha=.84$ for the CCSF scale and $\alpha=.79$ for the ITTF scale. These values correspond to those reported by Lübeck (2009).

Experimental manipulation: Focus during teaching practice reflection task. For the purpose of making academics reflect more deeply upon a particular approach to teaching and to test whether the salience of a particular teaching approach had an effect on academics' communication behavior, academics were given one of two sets of instructions:

Teacher-focus aimed to encourage the teacher to reflect on how they made the content comprehensible: "In courses, teachers decide on the content and mode of its transmission. As an expert in the area, you are required to prepare the content to be comprehensible. Please describe how you design your teaching for the content to be comprehensible."

Student-focus aimed to encourage teachers to reflect how students could be supported in learning: "In courses, students are demanded to acquire learning content and to apply it to their previous knowledge. As a teacher, you accompany students as they examine the content. Please describe how students can be supported during examination of the content." 
The resulting reflections were content-analyzed with regard to indicators of strategies within the two teaching orientations (Kember, 1997; Kember \& Kwan, 2000; Norton, Richardson, Hartley, Newstead, \& Mayes, 2005; Postareff \& Lindblom-Ylänne, 2008; Braun \& Hannover, 2008; Winteler, 2006). The analysis followed the same procedure as the analysis of the email answers described in analyzing the email answers.

The academics' criteria for good teaching that were assessed at the end of the survey as a manipulation check also were grouped systematically into one of the two orientations.

Student's request. The fictitious request was constructed based on students' real questions and on learning-related issues derived from the literature (Myers, Martin, \& Knapp, 2005). The request from the viewpoint of a female student, addressed how stressful the self-learning effort between classes was for her. She asked the lecturer why she needed to invest time between classes and how she could use this time most efficiently.

The topic of self-learning and learning strategies was chosen because it constitutes a topic independent of disciplinary content and is at the same time extremely relevant in the context of educational development for academic teachers (Wingate, 2007).

Open question on criterion for good teaching. At the end of the survey, academics were asked an open question worded the following way: "What is your most important criterion for good teaching?"

Answers to this open question were analyzed using the same categories as explained above for the reflection task (Krippendorff's $\alpha=.93$ ). As the question was the same for both experimental groups, differences in the answers between reflection focus groups point to effects of the experimental manipulation.

Dependent measure: University academics' communication in response to the student's request.

By means of content analysis, two broader categories with subsequent sub-categories were identified: Academics tended to (1) provide reasons why students should engage in self-learning and (2) give advice on how students should carry out self-learning. As dependent variables in the statistical analyses, the proportion of words assigned to one of the three categories (reasons, advice, and others) normalized to the length of the email response were used. A second group of dependent variables consisted of more detailed content categories identified and coded within the units coded as reasons and advice.

Procedure. Academics' email answers to the student's request were analyzed in two steps: First, answers were divided into proportions that could be allocated to the student's first question of why self-learning effort was necessary (reasons) and the student's second question of how the student could spend her time effectively or how she could reduce her stress (advice). Less than $20 \%$ of the data were coded into an additional category of "other" (i.e. for example, greeting and farewell). In the second step of analyzing the email answers, a detailed coding scheme for both previously defined categories was developed that included the division of extracts and the assignment to a certain content category. Therefore, two raters read through all the data and developed a first draft of the coding schemes. After the two raters agreed on a coding scheme, a third rater was trained in using the scheme. Interrater reliability was calculated with the codings of one of the raters who developed the scheme and this third person who applied the final coding scheme to at least $25 \%$ of the data.

Reasons. Based on Kember and Kwan (2000), two categories of reasons for self-learning were identified: external and internal motivators. As external motivators the following were defined: reasons that referred to external circumstances within the study situation, the content, or the teacher, such as study regulations, exam preparation, the requirement of the subject, the academic's appraisal or a benefit for a teacher/content activity in class e.g. „The post-processing is important for your exam preparation". As internal motivators the following were defined: those reasons with more intrinsic benefits for the student and her learning process, such as a benefit for a student/learning activity in class, the student's expansion of competencies, or the possibility to independently deal with the subject e.g. „Only through independent preparation and post-processing you can achieve personal understanding”.

Advice. For academics' advice information was defined how to spend self-learning time effectively and reduce stress (Biggs, Kember, \& Leung, 2001; Baeten et al., 2010; Devlin, 2002; Entwistle \& McCune, 2004). This resulted in a coding scheme consisting of four categories plus a category "other":

(1) A surface learning strategy: when academics gave specific advice on what content the student needed to focus her learning.

(2) Cognitive deep learning strategy: when the academic advised organization, elaboration, or metacognitive strategies. 
(3) Resource management strategy: Advice involving coordinating timetables, working in groups, managing time, or addressing the student's responsibility or learning effort.

(4) No specific strategy reference: When comments addressed the student's second question but contained no actual advice;

(5) "Other aspects" provided the fifth category, with $5.6 \%$ of the answers.

Interrater reliabilities for the number of aspects assigned to those categories were $\alpha=0.79$ for the cognitive surface strategy, $\alpha=0.93$ for cognitive deep strategies, $\alpha=0.92$ for resource management, and $\alpha=0.93$ for advice that was not related to strategies.

As the dependent variable in the following statistical analyses, the proportions of aspects assigned to those categories normalized to the number of aspects in the email previously coded within the reasons and advice categories were used.

\section{Results}

In the following, descriptive findings from the content analysis of academics' emails are reported before results regarding the research questions.

The data from the content analyses consisted of proportions calculated from the codings.

\section{Descriptive results}

Academics wrote answers consisting, on average, of 154 words $(S D=73.42$, Med $=142, \operatorname{Min}=24, \operatorname{Max}=379)$. Overall, half of the academics' answers referred to the student's question' about how to use self-learning time effectively and how to reduce stress, whereas participants only allocated about one third of their answer to explain why self-learning effort was necessary. Of the reasons academics mentioned, almost equal proportions were coded as external and internal motivators. Within the external motivators, academics mostly explained that self-learning would benefit the student in class (17\% of all reasons for student self-learning, and 35\% of external motivators): through her preparation, the student would be able to ask questions and the academics can focus on more difficult content, or the student would be able to more easily follow the academics' presentation of content (all related to teacher/content strategies in class). The most often mentioned internal motivator (20\% of all reasons and $40 \%$ of internal motivators) referred to the student's opportunity to independently deal with the subject. The greatest proportion of advice was coded as resource-management strategies (34\% of advice). Within those, academics most often referred to the student's time-management strategies (11\% of all advice and 32\% of resource-management strategies).

\section{Research question 1: Association with approaches to teaching}

The main research question addressed the association between academics' teaching approaches and their behavior in answering a student's request.

Regression analyses showed no significant effects of approaches to teaching on the proportion of explanation. Concerning the association of approaches to teaching and advice giving, no significant association was found between the proportion of advice academics gave and the ATI-R scales. Regarding the types of advice given, answers related to deep-learning strategies showed a positive association to the ATI-R CCSF scale. Therefore, in the context of research question 1, a positive association of the ATI-R CCSF scale with deep-learning strategies was found.

Gender indicated that compared to men, women mentioned fewer external motivators, $b^{*}=-0.81, z=-2.04, p=.041$, and more resource-management strategies, $b^{*}=0.66, z=2.08, p=.037$. No significant effects were found for research experience.

\section{Research question 2: Salience of one teaching approach}

The regression analysis, which focuses on the instruction to reflect and the proportions of teacher/content- and student/learning-oriented extracts within the reflections as dependent variables revealed that academics in the teacher-focused condition mentioned a greater proportion of teacher/content-oriented extracts than academics who received the instruction to reflect on the students' learning, $b^{*}=-1.16, z=-4.00, p<.001$. No differences were found for student/learning-oriented extracts. For the covariates, a trend was found whereby academics who mentioned fewer student/learning-oriented units had higher values on the ATI-R ITTF scale, $b^{*}=-0.31, z=-1.90, p=.06$, and had more research experience, $b^{*}=-0.46, z=-2.38, p=.017$. No significant effect of instruction was found for the length of the reflections. The manipulation check revealed no significant differences in the category of criteria for 
good teaching. Any effect of the manipulated instruction's ability to encourage the salience of one teaching approach did not seem to last during the academic's response to the student's email. However, as the academics' reflections differed in their proportion of teacher/content-oriented extracts. Academics who received the student-focused instructions to reflect on their teaching practice gave less advice than academics who received the teacher-focused instructions $-b^{*}=-0.62, z=-2.07, p=.039$. This addresses research question 1 that student-focused approaches to teaching are associated with giving less advice.

\section{Research question 3: Association with discipline}

Regression analyses revealed significant associations between discipline and some levels of communication behavior: Academics from the soft sciences wrote longer emails than academics from the hard sciences, $b^{*}=0.67, z=2.44, p$ $=.018$. Additionally, academics in the soft sciences showed a trend for a higher proportion of reasons in their email answer, $b^{*}=0.59, z=1.82, p=.070$ as well as for fewer external motivators, $b^{*}=-0.86, z=-2.04, p=.042$, and more resource management strategies than academics in the hard disciplines, $b^{*}=0.72, z=2.17, p=.030$.

\section{Discussion}

No significant associations between academics' scores on the ATI-R and their explanation behavior were observed. Concerning academics' advice-giving behavior, the data did not show a statistically significant association between the absolute proportion of advice given and an academics' approach to teaching. However, data revealed a positive association between giving advice for deep-learning strategies and the student-oriented approach to teaching; the data also showed a negative association between reflection instructions that encouraged a student-focused approach and the proportion of advice academics gave in their answers.

The attempt to make one approach to teaching salient by instructing academics to reflect either on themselves and their content or on the students and their learning led to variations in the reflections of teacher/content-oriented teaching practice. Academics who received the student-focused instructions to reflect on their teaching practice gave less advice in their email response to the student. However, no variations were found in the proportion of student/learning-oriented practice or concerning the manipulation check at the end of the survey.

Regarding the effect of discipline on academics' communication behavior, academics from the soft disciplines wrote longer email answers with a greater proportion of reasons. Additionally, within the content categories, academics in the soft sciences mentioned fewer external motivators in the explanation category and more resource management strategies in the advice category.

Academics' responses that showed a student focus were positively associated with the proportion of deep learning strategies they advised students to use during self-learning. Furthermore, when academics received the student-focused instruction to reflect prior to answering the email, which asked them to reflect on the student and their learning, they gave less advice to the student. One significant association could be observed with the ATI-R measures: The higher the academics' student focus, as measured by the ATI-R, the deeper learning strategies they advised. This fits results of previous research, where students taught by academics who had a student/learning-oriented teaching approach applied fewer surface-learning strategies and, conversely, students taught by academics with an information-transmission (teacher/content) approach used more surface strategies and fewer deep strategies (Gibbs \& Coffey, 2004; Trigwell et al., 1999).

Furthermore, when academics were given instructions to reflect on their teaching practice focusing on the student and their learning (compared to on themselves and the content) before replying to the student's email request, they gave less advice. This result might indicate that the student/learning approach emphasizes students' own responsibility for their learning and push the student just enough to enable them to engage in a variety of learning activities.

Beside these quantitative analyses, findings were obtained by analyzing the content of academics' answers: Regarding academics' advising, about half of the academics' answers addressed the student's question on how to use her self-learning time effectively and how to reduce her stress. Within the advice, academics most often mentioned strategies that referred to resource management (34\% of mentioned pieces of advice). In fact, these strategies were mentioned more often than all other learning strategies. This demonstrates that academics mentioned self-learning time as an opportunity for students to manage resources, such as coordinating their timetables, performing group work, managing their time, or using their own responsibility as a motivating resource for self-learning effort. Therefore, academics advised many relevant strategies that emphasize, to an extent, basic conditions that students can affect. Academics less often advised concrete learning strategies, such as strategies for working with texts, elaborating or dealing critically with information (together, surface and deep learning strategies made up less than 30\% 
of the advice). This might indicate that academics in higher education do not see themselves entirely as supporters for students' learning, but rather as facilitators in an environment where learning is possible. A view, however, especially needed during the transition from school to university (Wingate, 2007).

In $22 \%$ of their answers, academics asked the student to contact them at a later date, e.g. in their consultation hour or before/after class. This could reflect that academics need efficiency in their working life: It seems to be more efficient to clarify questions concerning students' learning directly before or after class than to write emails.

What effect does a salient approach to teaching have on academics' communication behavior?

Before academics responded to the student's email, one of two sets of instructions were presented that encouraged them to reflect on their personal teaching practice. One set focused on the academics and their content, while the other focused on the students and their learning. These different instructions resulted in systematically different descriptions, but only for the instructions that emphasized the teacher/content orientation. This might indicate that the teacher/content-focused approach to teaching can be influenced more easily than the student-/learning-focused approach. One possible explanation for this could be that the student/learning-focused approach is indeed a more complete approach to teaching that goes beyond yet includes (most of) the teacher/content-focused approach (see e.g. Postareff \& Lindblom-Ylänne, 2008). Therefore, most academics may be able to retrieve teacher/content-focused aspects of teaching, but only academics with the more developed student/learning-focused approach can retrieve student/learning-oriented aspects.

The manipulation check did not indicate that salience of one teaching approach (introduced by the reflection instructions) was present when the academics answered the student's email. However, a significant variation in the proportion of advice academics gave could be traced back to the reflection instructions. Therefore, it did have some effect, but this needs to be replicated and examined in more detail in further studies to identify how it might be used in educational development initiatives.

How is an academic's discipline associated with how they explain reasons for self-learning and give advice?

Academic discipline showed some association with communication behavior: Academics from soft disciplines showed a trend toward writing longer answers than academics from hard disciplines. This can be explained by other research on epistemological differences between academic disciplines, in which soft sciences are considered non-paradigmatic and reiterative, and where knowledge is considered more complex and less certain, whereas the hard sciences tend to deal with clearer paradigms and are more consensual, where knowledge is considered rather certain (e.g. Muis et al., 2006; Neumann et al., 2002; Päuler \& Jucks, 2017). Further, academics' epistemological beliefs have been shown to associate with their approaches to teaching: The teaching approaches of academics with more relativistic epistemological beliefs were associated positively with student/learning-oriented approaches and negatively with teacher/content-oriented approaches (Päuler \& Jucks, 2017; Roth \& Weinstock, 2013). Therefore, academics from these different groups of disciplines are assumed to have different ways of behaving in relation to their knowledge and ideas (Lindblom-Ylänne, Trigwell, Nevgi, \& Ashwin, 2006), which shows in the data. To answer the student's request in more detail corresponds with more discourse and discussion in the soft sciences, whereas within the hard sciences a more concise communication style is appropriate for content that is often transmitted by an expert (Kember \& Leung, 2006).

The findings suggest that this conciseness within the hard sciences especially extends to the explanation of reasons for self-learning effort as well as to the proportion of advice regarding what resources the student could use for effective self-learning. Specifically, academics from the soft disciplines mentioned a higher proportion of reasons for self-learning and more resource management strategies than academics from the hard disciplines. Within the hard disciplines, extrinsic reasons to motivate students to invest effort in self-learning seem to be more prominent.

\section{Implications, limitations and further research}

The research findings can be placed within the framework of the scholarship of teaching (Trigwell \& Shale, 2004). Albeit small, the effects support the assumption that there is a logical association between approaches to teaching and teaching practice. The results on academics' explanation and advice-giving behavior showed that academics offer quite a broad repertoire of reasons for why students should engage in self-learning and advice on what types of learning strategies they can use. Further, the content of advised strategies focused mainly on how students can manage their resources and not so much on deep learning strategies, indicating that academics need to undergo further educational development to become experts on how students learn (Wingate, 2007). Student-focused academics advised more of those deep learning strategies, indicating that development initiatives that focus on 
approaches to teaching might be of particular benefit. The substantial disciplinary variation in academics' explanation and advice-giving behavior highlights the need for discipline-based initiatives.

A limitation of the study was its rather low statistical power, due to the sample size. Only small effects in their communication behavior could be expected, as an academic's teaching approach is assumed to be only one of many situational and personal factors that influence their communication. Voluntary participation could have reduced variation in email answers due to a self-selection of the most motivated participants.

To operationalize teaching behavior, the research design required academics to answer a student's email request. One criticism of this choice could be that the most prominent teaching behavior would involve the academic and the students interacting face-to-face during class. However, global face-to-face teaching behavior would be an even more complex dependent variable, making associations with approaches to teaching even harder to uncover. Nonetheless, future research is needed to identify how teaching practice and approaches to teaching really are associated, as previous research, mostly qualitative, sometimes shows inconsistent patterns (Devlin, 2006).

\section{Conclusion}

Previous research on approaches to teaching lack the observation of teaching practice which this research operationalized by an online out-of-class instructional setting. The variations in how academics responded to and gave advice to students were more related to the academics' disciplines rather than to their approaches to teaching. Further research is needed on the possibilities to make an academics' particular approach to teaching salient. Disciplinary considerations need to be addressed in educational initiatives that are targeted to different disciplines.

\section{Acknowledgements}

We thank Christina Blabl, Christina Hanna, and Daniel Ruholl for their support with the content analyses, Katrin Burmester for assistance with the manuscript and Celeste Brennecka for language editing.

\section{References}

Amudsen, C. \& Wilson, M. (2012). Are we asking the right questions? A conceptual review of the educational development literature in higher education. Review of Educational Research, 82, 90-126. https://doi.org/10.3102/0034654312438409

Baeten, M., Kyndt, E., Struyven, K., \& Dochy, F. (2010). Using student-centred learning environments to stimulate deep approaches to learning: Factors encouraging or discouraging their effectiveness. Educational Research Review, 5(3), 243-260. https://doi.org/10.1016/j.edurev.2010.06.001

Biggs, J. B., Kember, D., \& Leung, D. Y. P. (2001). The revised two-factor Study Process Questionnaire: R-SPQ-2F. British Journal of Educational Psychology, 71(1), 133-149. https://doi.org/10.1348/000709901158433

Braun, E., \& Hannover, B. (2008). Zum Zusammenhang zwischen Lehr-Orientierung und Lehr-Gestaltung von Hochschuldozierenden und subjektivem Kompetenzzuwachs bei Studierenden. Zeitschrift für Erziehungswissenschaft, 277-291. https://doi.org/10.1007/978-3-531-91775-7_18

Devlin, M. (2002). Taking responsibility for learning isn't everything: A case for developing tertiary students' conceptions of learning. Teaching in Higher Education, 7(2) 125-138. https://doi.org/10.1080/13562510220124231

Devlin, M. (2006). Challenging accepted wisdom about the place of conceptions of teaching in university teaching improvement. International Journal of Teaching and Learning in Higher Education, 18(2), 112-119.

Eley, M. G. (2006). Teachers' conceptions of teaching, and the making of specific decisions in planning to teach. Higher Education, 51(2), 191-214. https://doi.org/10.1007/s10734-004-6382-9

Entwistle, N., \& McCune, V. (2004). The Conceptual Bases of Study Strategy Inventories. Educational Psychology Review, 16(4), 325-345. https://doi.org/10.1007/s10648-004-0003-0

Gibbs, G., \& Coffey, M. (2004). The impact of training of university teachers on their teaching skills, their approach to teaching and the approach to learning of their students. Active Learning in Higher Education, 5(1), 87-100. https://doi.org/10.1177/1469787404040463

Gueorguieva, R., Rosenheck, R., \& Zelterman, D. (2008). Dirichlet component regression and its applications to psychiatric data. Computational Statistics and Data Analysis, 52(12), 5344-5355. https://doi.org/10.1016/j.csda.2008.05.030

Hijazi, R. H., \& Jernigan, R. W. (2009). Modelling compositional data using dirichlet regression models. Journal of 
Applied Probability \& Statistics, 4(1), 77-91.

Ho, A., Watkins, D., \& Kelly, M. (2001). The conceptual change approach to improving teaching and learning: An evaluation of a Hong Kong staff development program. Higher Education, 42, 143-169. https://doi.org/10.1023/A:1017546216800

Hofer, B. K. (2000). Dimensionality and disciplinary differences in personal epistemology. Contemporary Educational Psychology, 25(4), 378-405. https://doi.org/10.1006/ceps.1999.1026

Jucks, R. \& Brummernhenrich, B. (2016). Out-of-classroom interactions between teachers and students: advising, tutoring, mentoring, and coaching. In P. L. Witt (Ed.), Handbooks of Communication Science: Vol. 16. Communication and Learning (pp. 553-572). Berlin, Germany: DeGruyter Mouton. https://doi.org/10.1515/9781501502446-023

Kane, R., Sandretto, S., \& Heath, C. (2002). Telling half the story: A critical review of research on the teaching beliefs and practices of university academics. Review of Educational Research, 72(2), 177-228. https://doi.org/10.3102/00346543072002177

Kember, D. (1997). A reconceptualization of the research into university academics' conceptions of teaching. Learning and Instruction, 7(3), 255-275. https://doi.org/10.1016/S0959-4752(96)00028-X

Kember, D., \& Kwan, K.-P. (2000). Lecturers' approaches to teaching and their relationship to conceptions of good teaching. Instructional Science, 28(5-6), 469-490. doi:10.1007/978-94-010-0593-7

Kember, D., \& Leung, D. Y. P. (2006). Characterizing a teaching and learning environment conducive to making demands on students while not making their workload excessive. Studies in Higher Education, 31(2), 185-198. https://doi.org/10.1080/03075070600572074

Lindblom-Ylänne, S., Trigwell, K., Nevgi, A., \& Ashwin, P. (2006). How approaches to teaching are affected by discipline and teaching context. Studies in Higher Education, 31(3), 285-298. https://doi.org/10.1080/03075070600680539

Lübeck, D. (2009). Lehransätze in der Hochschullehre [Approaches to teaching in higher education] (Doctoral thesis). Freie Universität Berlin, Berlin. Retrieved from http://www.diss.fu-berlin.de/diss/servlets/MCRFileNodeServlet/FUDISS_derivate_000000005893/01_Dissertat ionsschrift_DietrunLuebeck.pdf (17.02.2012).

Martin, E., Prosser, M., Trigwell, K., Ramsden, P., \& Benjamin, J. (2000). What university teachers teach and how they teach it. Instructional Science, 28, 387-412. https://doi.org/10.1023/A:1026559912774

Muis, K. R., Bendixen, L. D., \& Haerle, F. C. (2006). Domain-generality and domain-specificity in personal epistemology research: Philosophical and empirical reflections in the development of a theoretical framework. Educational Psychology Review, 18(1), 3-54. https://doi.org/10.1007/s10648-006-9003-6

Myers, S. A., Martin, M. M., \& Knapp, J. L. (2005). Perceived instructor in-class communicative behaviors as a predictor of student participation in out of class communication. Communication Quarterly, 53(4), 437-450. https://doi.org/10.1080/01463370500102046

Neumann, R., Parry, S., \& Becher, T. (2002). Teaching and learning in their disciplinary context: A conceptual analysis. Studies in Higher Education, 27(4), 405-417. https://doi.org/10.1080/0307507022000011525

Neumann, R. (2009). Disciplinarity. In M. Tight, K. Mo Hok (Eds.), The Routledge International Handbook of Higher Education (pp. 487-500), New York: Routledge

Norton, L., Richardson, J. T. E., Hartley, J., Newstead, S., \& Mayes, J. (2005). Teachers' beliefs and intentions concerning teaching in higher education. Higher Education, 50(4), 537-571. https://doi.org/10.1007/s10734-004-6363-z

Päuler-Kuppinger, L. \& Jucks, R. (2017). Perspectives on Teaching: Conceptions of Teaching and Epistemological Beliefs of University Academics and Students in Different Domains. Active Learning in Higher Education, 18, 63-76. https://doi.org/10.1177/1469787417693507

Postareff, L., \& Lindblom-Ylänne, S. (2008). Variation in teachers' descriptions of teaching: Broadening the understanding of teaching in higher education. Learning and Instruction, 18(2), 109-120. https://doi.org/10.1016/j.learninstruc.2007.01.008

Roth, G., \& Weinstock, M. (2013). Teachers' epistemological beliefs as an antecedent of autonomy-supportive 
teaching. Motivation and Emotion, 37(3), 402-412. https://doi.org/10.1007/s11031-012-9338-x

Stes, A., \& Van Petegem, P. (2014). Profiling approaches to teaching in higher education: a cluster-analytic study. Studies in Higher Education, 39(4), 644-658. https://doi.org/10.1080/03075079.2012.729032

Trigwell, K. (2012). Relations between teachers' emotions in teaching and their approaches to teaching in higher education. Instructional Science, 40(3), 607-621. https://doi.org/10.1007/s11251-011-9192-3

Trigwell, K., \& Prosser, M. (1996). Congruence between intention and strategy in university science teachers' approaches to teaching. Higher Education, 32(1), 77-87. https://doi.org/10.1007/BF00139219

Trigwell, K., Prosser, M., \& Ginns, P. (2005). Phenomenographic pedagogy and a revised Approaches to teaching inventory. Higher Education Research \& Development, 24(4), 349-360. https://doi.org/10.1080/07294360500284730

Trigwell, K., Prosser, M., \& Waterhouse, F. (1999). Relations between teachers' approaches to teaching and students' approaches to learning. Higher Education, 37(1), 57-70. https://doi.org/10.1023/A:1003548313194

Trigwell, K., \& Shale, S. (2004). Student learning and the scholarship of university teaching. Studies in Higher Education, 29(4), 523-536. https://doi.org/10.1080/0307507042000236407

Waldeck, J., Kearney, P., \& Plax, T. (2001). Teacher e-mail message strategies and students' willingness to communicate online. Journal of Applied Communication Research, 29(1), 54-70. https://doi.org/10.1080/00909880128099

Winteler, A. (2006). Lehrende an Hochschulen. In A. Krapp \& B. Weidenmann (Eds.), Pädagogische Psychologie: Ein Lehrbuch (pp. 232-245). Weinheim: Beltz.

Wingate, U. (2007). A framework for transition: supporting 'learning to learn' in higher education. Higher Education Quarterly, 61(3), 391-405. https://doi.org/10.1111/j.1468-2273.2007.00361.x

Young, P. (2006). Out of balance: lecturers' perceptions of differential status and rewards in relation to teaching and research. Teaching in Higher Education, 11(2), 191-202. https://doi.org/10.1080/13562510500527727 